\title{
"YENI ISTANBUL": THE EXPANSION OF A GLOBAL CITY
}

\author{
Dimensions of the new mega projects in global cities situated at \\ the periphery of North-American and West-European capitalist \\ economies from a governance and planning process perspective: \\ case study of Istanbul Airport
}

Author 1 GEAMBAZU, Ion Mincu University of Architecture and Urban Planning; Romania

\begin{abstract}
The spread of neo-liberal political and economic ideology and the proliferation of global capital have created new opportunities and challenges for cities everywhere (Sassen 2012). Within the urban planning discourse, it is generally assumed that globalization leads to the same type of transformations and urban development trends everywhere in the world. However, it cannot create a certain prototype for spatial development or a new spatial order for cities. Rather, it gives a variety of spatial patterns, also called "global urban forms". Recently, these forms have identified themselves spatially within a series of "mega-projects", their intensity being felt in today's global cities, North-American and West-European, but with a domino effect, especially in the cities situated at the periphery of these capitalist economies. Total global megaproject spending is assessed at USD 6-9 trillion annually, or 8 percent of total global GDP, which denotes the biggest investment boom in human history. Never has systematic and valid knowledge about mega projects therefore been more important to inform policy, practice, and public debate in this highly costly area of business and government. It is argued that the conventional way of managing mega projects has reached a "tension point," where tradition is challenged and reform is emerging (Flyvbjerg, 2011). These kind of projects often take place within fragmented and entrepreneurial forms of governance (Harvey 1989; Healey 1997; Gordon 1997a, 1997b; Feldman 1999; Feinstein 2001; Granath 2005; Butler 2007) represented by public-private partnerships, in a societal environment of increased capital mobility and inter-urban competition (Malone 1996). Hence, it is argued, that mega projects have been examples of new governance styles and policy targets, but also object of intensive local planning debates and conflicts based on different actors (authorities, planners, residents, environmental groups, developers, etc.) holding an equal number of views (Hoyle, 2002) which are often difficult to reconcile. Strongly linked to the 2023 Vision of Turkey, the $3^{\text {rd }}$ airport, Istanbul Airport is one of the mega projects that will bring Turkey among top 10 economically powerful countries. Istanbul
\end{abstract}


Airport distinguishes itself from a myriad of other build-operate-transfer projects by its governance dynamics and planning process. The study employs discourse analysis through which extracts lesson from the decision-making process that will inform planners in Istanbul and beyond.

\section{Keywords}

Urban governance, planning process, mega projects, Istanbul, discourse

\section{The new mega projects}

\subsection{Definition and characteristics of the new mega projects}

It is known that mega projects have been constructed since ancient time, if we should look at the Maya cities in Mexico or the pyramids in Egypt or the road networks of the Roman Empire, but the first time they were acknowledged as a concept, was in 1970's in order to describe large scale projects by Canadian government and the American contractor Bechtel, who is also the company that constructed The Channel tunnel between England and France, the longest undersea portion of any tunnel in the world. (Merrow et al., 1988)

After WWII, the Fordist state engaged in a series of "mega projects" for the restructuration of urban tissue, the efforts to create a modern society with express ways and high rise buildings. Jane Jacobs (1961 pg. 25), ironically named those efforts and the city:

"radiant garden city beautiful". In the "great mega-project era" of the 1950s and 1960s (Altshuler and Luberoff, 2003), the projects were monolithic constructions with little attention for citizen participation and environmental issues. Overcoming the social movements of 1960-1970s, the restrictions of the government and the decentralization associated with neoliberalism, these types of developments unwind, but they do not totally disappear (Altshuler si Luberoff 2003). Surpassing these critics on the left, critics on the right argue that these developments were an unnecessary intrusion of the forces of the government and led to unjustified expropriations of private property (Anderson 1964).

Today's infrastructure mega projects play a key role in nothing less than the creation of what many see as a new world order where people, goods, energy, information and money move about with unprecedented ease. Here the politics of distance is the elimination of distance. (Flyvbjerg, B., Bruzelius, N. and Rothengatter, W., 2003) Mega projects are central to the new politics of distance because infrastructure is increasingly being built as mega projects. Thus, the past decade has seen a sharp increase in the magnitude, frequency and geographical spread of major infrastructure projects, supported by a mixture of national and supranational government, private capital and development banks, namely multibilliondollar infrastructure projects such as airports, high-speed rail, urban rail, tunnels, bridges, ports, motorways, dams, power plants, water projects, oil and gas extraction projects, information and telecommunications technology systems, and so on.

Never in the history of humankind have we built more, or more expensive, infrastructure projects. To put it in numbers, the size of infrastructure projects has grown by " 1.5 to $2.5 \%$ 
annually in real terms of the past century "(Flyvbjerg, 2014, p.4). "This is the "tension point" where convention meets reform, power balances change, and new things are happening. In short, it is the place to be as a megaproject planner, manager, scholar, student, owner, or interested citizen." (Flyvbjerg 2014, p.22)

But how big is actually this whole mega project industry? McKinsey Global Institutes (2013) evaluated it with a spending need of a total of 57 trillion in between 2013-2030 (McKinsey \& Company, 2013). The Economist estimates a total of 20 trillion until $2030^{1}$ and calls infrastructure mega projects "the biggest investment boom in history".(Flyvbjerg, 2014, 2017) Furthermore, these type of projects have proven themselves recession proof, the downturn of 2008 was not even close abating to their relentless drive and with so many resources and side effects tied to them, their study, understanding and management has never been more important. (Flyvbjerg el al., 2003; Flyvbjerg, 2011,2014,2017)

Leher and Laidley (2008) make a distinction between 'old' and 'new' mega projects' ${ }^{2}$ in the development of urban economies. The current mode of large-scale urban development is different from its predecessor in so far as its focus is flexible and diverse rather than singular and imposing. However, the diversity that the new approach offers, forecloses upon a wide variety of social practices, reproducing rather than resolving urban inequality and disenfranchisement, shifting from collective benefits to a more individualized form of public benefits. (Leher and Laidley, 2008)

The 'new' mega-projects take the form of vast complexes characterized by a mix of uses, a variety of financing techniques, and a combination of public- and private-sector initiators (Lehrer and Laidley, 2008). The construction of new transport infrastructures, or the extension of existing ones, and complex building projects are examples of these new megaprojects (Diaz Orueta and Fainstein, 2008). They involve a transformation of urban space, its built form and its specific land use and changes the social practices in these urban landscapes (Van Marrewijk and Yanow, 2010;Lehrer and Laidley, 2008;Del Cerro Santamaria, 2013b). Importantly, new mega-projects are often undertaken by state actors operating in collaboration with private interests in the pursuit of gentrification of city-regions within a competitive global system (Lehrer and Laidley, 2008;Del Cerro Santamarı, 2013a: xxx).

\footnotetext{
${ }^{1}$ https://www.economist.com/finance-and-economics/2015/08/27/building-works

2 in their work Old Mega-Projects Newly Packaged? Waterfront Redevelopment in Toronto, 2008, where they study the particular development of Toronto's waterfront.
} 


\subsection{Performance paradox and impact in megaprojects}

The paradox is that when actual versus predicted performance of mega projects are compared, the picture is often dismal. At the same time as many more and much larger infrastructure projects are being proposed and built around the world, the poor performance of the majority of them is striking in terms of economy, environmental issues and public support. Much often the cost overruns are so high that projects who were planned to boost the economy become the main reason for its fall. (Peter W. G. Morris and George H. Hough, 1992; David Collingridge, 1992; Joseph S. Szyliowicz and Andrew R. Goetz, 1995; Mark Bovens and Paul 't Hart, 1996; Hall; Flyvbjerg, 2011).

A study of 130 mega projects constructed, but also under construction, comprising infrastructure mega projects solely of: road ways, rail ways, airports, metro lines, sea ports, rapid transit, bridges, tunnels and hybrid ones that encompass construction of new transportation means together with urban development, is made for this study with the scope of enlarging the findings in the literature review and test their accurateness. The projects are chosen with a conception year from 1950s until today, excluding statistical outliers. In line with the literature review it is clear, also with this study, that although 1950s and 1960s are considered to be the "mega project era", there is powerful increase in their development number after the 1980s until today. (Figure 1,2)

The main differences between the already constructed mega projects and the ones in construction is the growing budgets, not as trend line, but as a quantitative percentage of much costlier mega projects. While the trend considering the costs for the projects already constructed is decreasing, the new wave of mega projects, starting with mostly 2000, is rising, excluding the possible cost overrun until the completion of the project, which could lead to a sizable growth itself. The most expensive project under development is the High Speed 3-Northern Powerhouse Rail (39 billion \$ with an unrealistic 8 years estimation time until its finalization) and for the category of the already constructed ones, it is the AVE Spain's high-speed railway network (44 billion \$, within 24 years), the average of both categories being between $20-25$ billion $\$$ and more than $50 \%$ under 5 billion $\$$.

In contrast with the literature review, there is a decrease considering the period of time taken for the realization of mega projects, this being relatable to the technological advancement or the more efficient management tools employed in the planning process. Also, there is a big difference between the highest values of the constructed and under construction mega projects: The King Shaka International Airport is completed after 40 years, with the cost of 1 billion \$ and having a break from 1982 until its revival in 1990 and the Berlin-Brandenburg International Airport is the lengthiest so far for those under development, with already 24 years so far for the planning process and 11 years' delay from the initial finalization date. Breaks within the planning process are due to due to poor construction planning, execution, management, as well as corruption ${ }^{3}$, which lead to a cost overrun of 7 billion $\$$. (Figure 1,2,3,4)

${ }^{3}$ https://en.wikipedia.org/wiki/Berlin_Brandenburg_Airport 
Looking upon the graph on types of mega projects, the most expensive constructed mega project is the AVE - Spain's high-speed railway network and lengthiest is the Panama Canal. When we look at both trend lines of these types of projects, we can observe that any delay in a rail mega project becomes costlier than any delay in a canal mega project and taking into account all trend lines, airport mega projects are the costliest in terms of any setback or suspension. (Figure 3)

For the ones under construction, the representative is the costly mega project Stuttgart 21Germany (hybrid-railway and urban development) with a cost overrun of 2 billion euros and delay of 2 years so far and many problems considering the governance dynamics with opposition and heated debate on costs and benefits and environmental concerns ${ }^{4}$ (Figure 4)

In a comparison of costs and the development period on the type of mega project, constructed and under construction: road ways, rail ways, airports, metro lines, sea ports, rapid transit, bridges, tunnels and hybrid ones, the main conclusions are: the disappearance of the canal projects, the presence of sea ports mostly the construction of new touristic ports lately, the abrupt decrease in construction of bridge, road, metro line and airport projects and the increase in rapid transit, tunnel and hybrid projects. (Figure 3,4 )

If we look at the most expensive projects under construction from the last three types of project that lately gain popularity, they are: Stuttgart 21- Germany (hybrid-railway and urban development) stated before; WestConnex- Sydney, Australia (tunnel) with a cost overrun of 8.6 billion \$, in 2017 the projects third and final stage being abandoned, highly criticized on economic, social and process grounds and being subject of escalating public protests from academics, architects and resident action groups ${ }^{5}$; Grand Paris Express- France (rapid transit) with an unclear target date as 2030. (Figure $\mathrm{nr} .3,4$ )

Just as Merrow et al. (1988) stated before, interestingly, developing countries did not do better or worse than developed countries in executing mega-projects, the trend lines are close in terms of performance considering costs overruns and time spent of project development, although in literature review Flyvbjerg $(2011,2014)$ differentiates them in the railway sector. (Firgure nr. 5)

${ }^{4}$ https://en.wikipedia.org/wiki/Stuttgart_21\#Debate_and_opposition

${ }^{5}$ https://en.wikipedia.org/wiki/WestConnex\#Opposition 


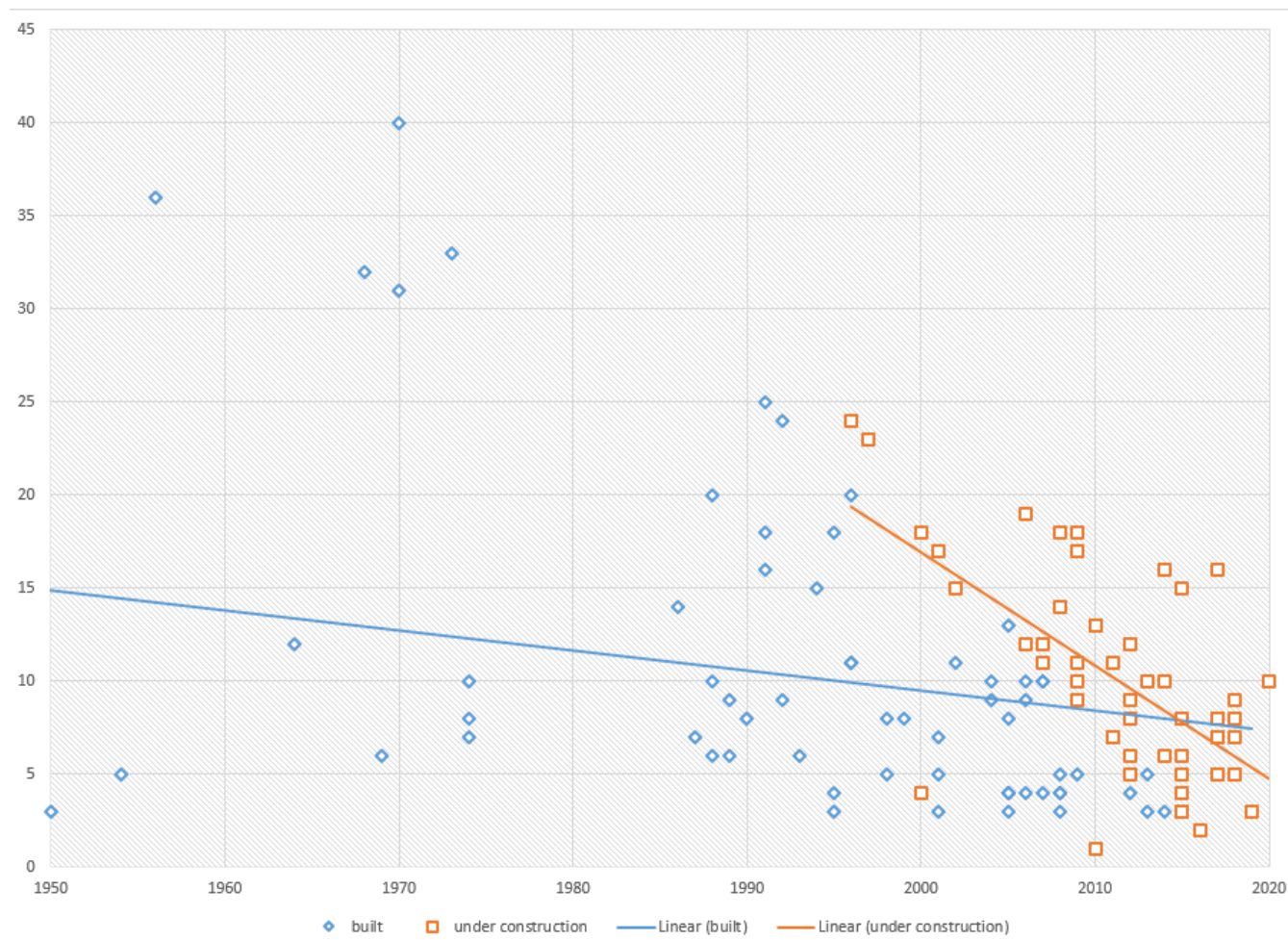

Figure 1 graph on built and under construction infrastructure mega projects (1950-2020) X axis: period, $Y$ axis: time line

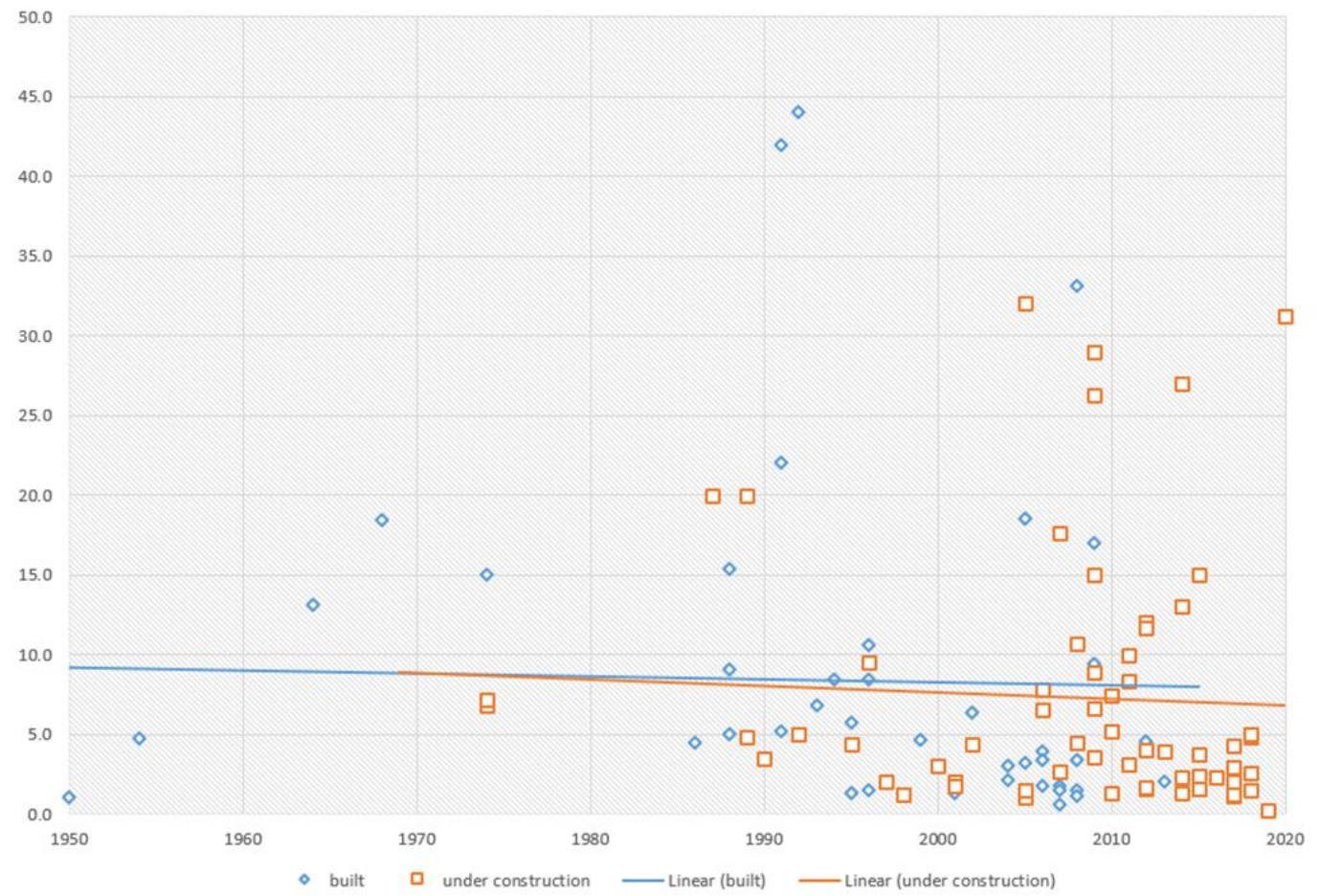

Figure 2 graph on built and under construction infrastructure mega projects (1950-2020) X axis: cost, $Y$ axis: time line 


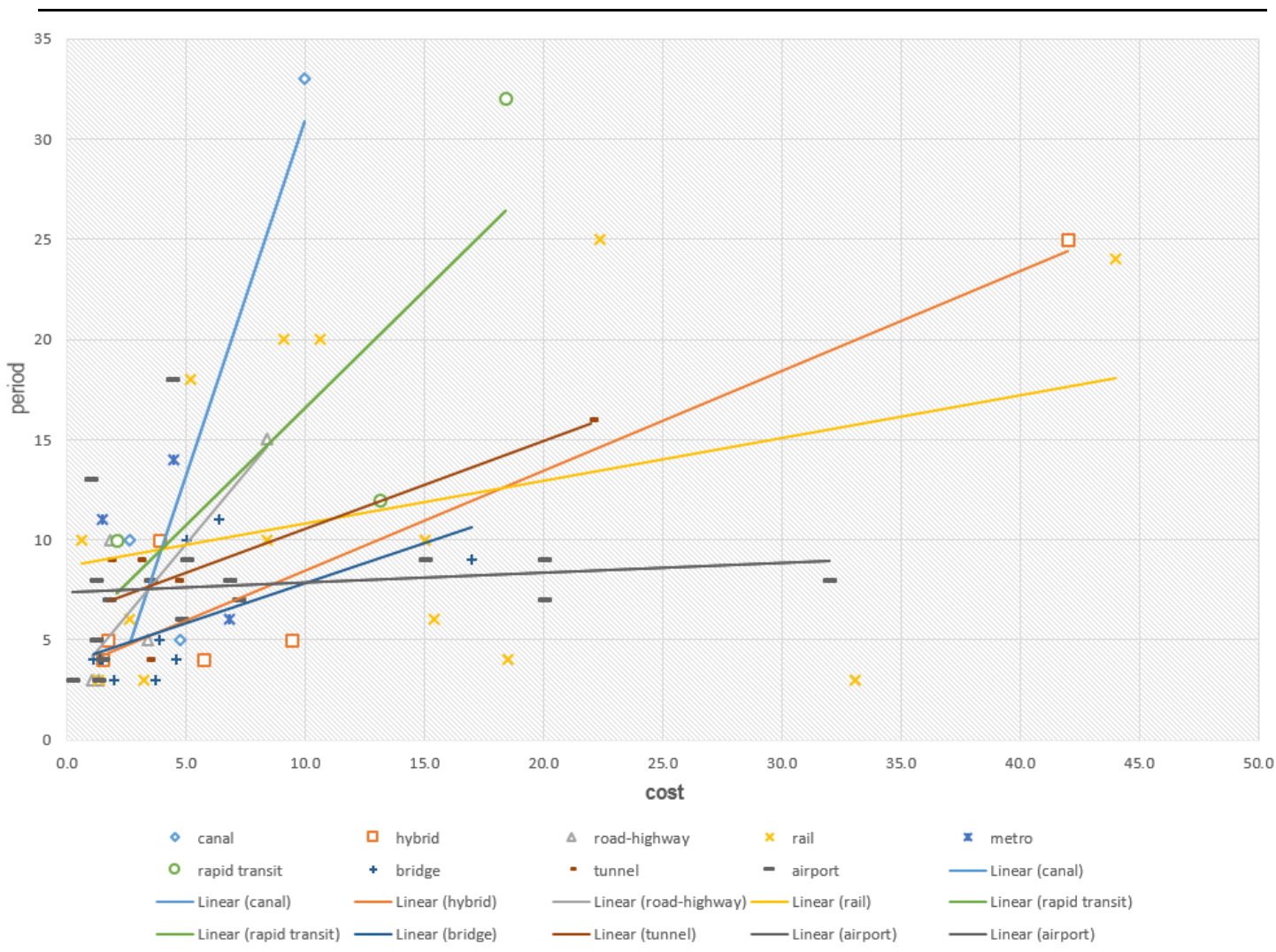

Figure 3: graph on built type of infrastructure mega projects (1950-2020)- X axis: period, $Y$ axis: cost, legend with types of mega projects;

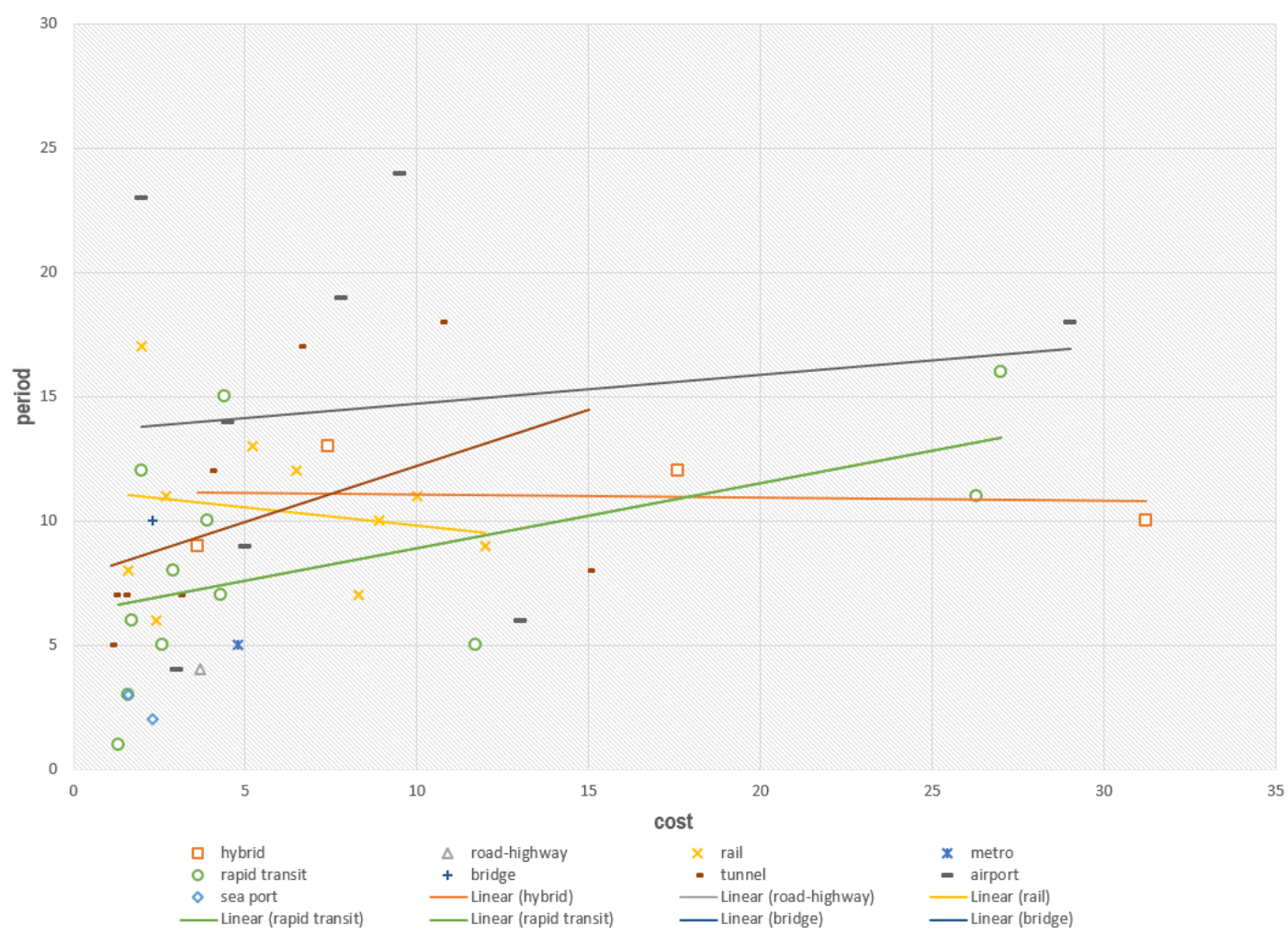


Figure 4: graph on under construction type of infrastructure mega projects (1950-2020)- $X$ axis: period, $\mathrm{Y}$ axis: cost, legend with types of mega projects;

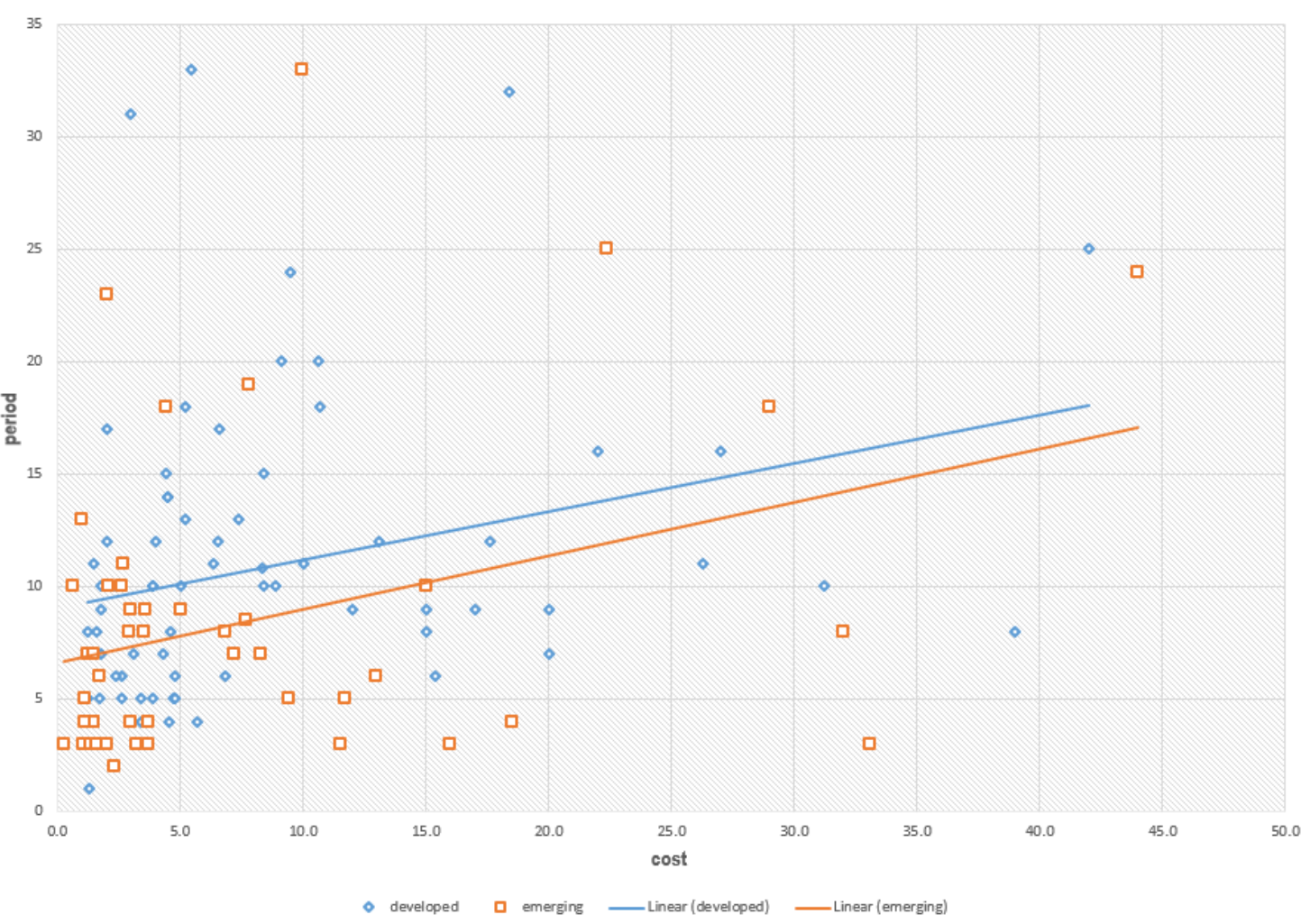

Figure 5: graph on infrastructure mega projects done in developed and emerging countries (1950-2020)- $X$ axis: period, $Y$ axis: cost, legend with types of mega projects 
Generally, these developments have been critically examined by many scholars, many of which share the belief that the mega projects are often not addressing the underlying, deeprooted problems of the cities and furthermore, ignoring the socially and economically unstable landscapes in which they often occur, veritably contributing to the escalation of inequality, polarization and deprivation in the city (Harvey 1989; 2005; Brownill 1990; Gordon 1997b; Hoyle 2000; Saarinen and Kumpulainen 2005; Butler 2007).

Often environmental and social effects of projects have not been taken into account during project development, or they have been severely miscalculated, such problems often destabilize habitats, communities and mega projects themselves, if not dealt with carefully. (Westport, CT: Praeger Publishers, 1998; Paris: OECD, 1993; Roger W. Vickerman, 1994)

Hirschman (1995: vii, xi) calls mega projects "privileged particles of the development process" and points out that often they are "trait making", that is, they are designed to ambitiously change the structure of society, as opposed to smaller and more conventional projects that are "trait taking," i.e., they fit into pre-existing structures and do not attempt to modify these. The framework of "exceptionality" associated with these initiatives favors a more autonomous, if not autocratic, dynamic marked by special plans and projects that relegate statutory norms and procedures to a secondary and subordinated place.

"Exceptionality" is a fundamental feature of the new urban policy, based on the primacy of project-based initiatives over regulatory plans and procedures. These changes involve, as stated before, among other things, the emergence of new policy tools, actors, and institutions, and they have important consequences for urban policy-making in general and for local democracy in particular, considering the increasing inequality in access to decisionmaking. Therefore, Brenner and Theodore (2004) argue that an important analysis aspect to identify the impact is the role of the state in these kinds of interventions (provision of subsidies, land or special treatment in the tax, etc.) and the level of involvement and its loyalty towards the goals for the public. Mega projects differentiate themselves by the way they combine social and environmental goals with the economical ones, the planning process and impact, reflecting in the same time the level of commitment that the host city has towards the concept of social equity (Fainstein 2009). 


\subsection{Performance paradox and impact in megaprojects Governance and planning process in mega projects}

In literature on mega projects, power, politics and conflicting and opposing interests are generally excluded (Clegg and Kreiner, 2013;Hodgson and Cicmil, 2006). An exception is Flybjerg et al. (2003) who suggest that a main cause of overruns is a lack of realism in initial cost estimates (see revious sub-chapter), motivated by vested interests of partners. Therefore, in his analysis in all continents and despite the differences of geography, political background, social or cultural aspects etc., he identifies a main common characteristic which is misinformation and lack of transparency considering the governance dynamics (Flyvbjerg et al. 2003). Civil society does not have the same say in this arena of public life as it does in others. Mega-projects often come draped in a politics of mistrust, characterized often by a 'democracy deficit' ${ }^{6}$. People fear that the political inequality in access to decision-making processes will lead to an unequal distribution of risks, burdens and benefits from projects. The general public is often skeptical or negative towards projects; the main causes of the mega projects paradox to be inadequate deliberation about risk and lack of accountability in the project decision-making process (Åsa Boholm and Ragnar L" ofstedt, 1999; James Bohman 1996)

One of the main issues that is both complex and likely to stir controversy is the question whether mega projects should be publicly or privately led. Understanding the appropriate roles of the two sectors is fundamental to the identification of a process for appraisal and decision making that will ultimately work in the public interest. For major infrastructure projects one could argue an either/or position on public versus private leadership: either such projects should be placed entirely within the public sector - for example in a government department, an agency or a state-owned enterprise - to ensure accountability through the rules of transparency and public control that apply to the public sector; or such projects should be placed entirely in the private sector - for example by means of buildoperate-transfer or other concession arrangement - to ensure accountability through competition and market control (Flyvbjerg, Bruzelius and Rothengatter, 2003)

It is argued that two main types of accountability define liberal democracies:

- public-sector accountability through transparency and public control

- private-sector accountability via competition and market control. (Flyvbjerg, Bruzelius and Rothengatter, 2003; Priemus, Flyvbjerg and Wee, 2008 p.138)

According to Clegg and Kreiner (2013) power in mega-projects has to be understood as relational effects, not as sources that can be held by partners. Project design, including contractual arrangements, and project cultures play a role in determining how managers and partners cooperate to achieve project objectives to a greater or lesser extent (Van Marrewijk

\footnotetext{
6 term coined by Scandinavians- who like other people around the world have experienced the construction of one megaproject after another during the past decade.
} 
et al., 2008). Therefore, Cicmil and Hodgson (2006b), suggest a more critical approach to understand the planning process of projects by exploring how the relationships between individuals and the project organization are produced and reproduced, how power relations create and sustain social relations.

\section{Analyzing planning through discourse}

The study of discourse is an important way of understanding how power is mediated in planning, capturing what planners do, how they respond to challenges, how are the planning problems being constructed, how are the solutions prioritized and how are the political pressures handled (Forester, 1989; Healey, 1992b; 1996; 1999; Innes, 1995; 1998) Discourse is a broad exchange of ideas and points of view among various individuals in a particular situation. In urban planning, a discourse might include the set of working papers, plan documents, media coverage, written or spoken statements expressing points of view on issues and proposed ways of addressing them and it has important implications in the policy analysis and planning itself.

Critical theories of Habermas, Derrida, and Foucault often provide the substantive underpinnings of discourse analysis. Many scholars such as Healy (1992b) and Forester (1989) have placed their planning analysis within the communicative rationality of Habermas ${ }^{7}$, referring to the capacity to engage in argumentation under conditions approximating to an ideal speech situation ('discourse', in Habermas' terminology), with the aim of achieving consensus (Dews, 1998).

Boyer (1983), on the other hand, employed Foucault's idea of a 'genealogical' framework ${ }^{8}$ to study how planning evolved over years. In Dreaming the Rational City' ${ }^{9}$, she focuses on the "apparatus of planning: what Focault has defined as the relationships among a set of distinct elements such as professional discourses, governmental institutions, administrative procedures, regulatory laws, legal concepts, architectural forms and plans, scientific statements, and moral proclamations" (p.xi) and on what happened once planning was called upon making cities "new areas for public policy" and " to maintain and preserve sound

\footnotetext{
7 "communicative rationality carries with it connotation based ultimately on the central experience of the unconstrained, unifying, consensus-bringing force of argumentative speech, in which different participants overcome their merely subjective views and, owing to the mutuality of rationally motivated conviction, 11 assure themselves of both the unity of the objective world and the intersubjectivity of their lifeworld" (Habermas, 1984, p. 10, cited in Rienstra and Hook, 2006, p.11).

${ }^{8}$ Foucault's genealogical history seeks to deconstruct what was previously regarded as unified (i.e. history as a chronological pattern of events emanating from a mystified but all-determining point of departure), while also attempting to identify an underlying continuity which is the product of "discontinuous systematicities".

${ }^{9}$ Dreaming the Rational City is both a history of the city planning profession in the United States and a major polemical statement about the effort to plan and reform the American city. Boyer shows why city planning, which had so much promise at the outset for making cities more liveable, largely failed. She reveals planning's real responsibilities and goals, including the kind of "rational order" that was actually forseen by the planning mentality, and concludes that the planners have continuously served the needs of the dominant capitalist economy.
} 
capital investments already committed to infrastructure and real estate from areas experiencing blight, abandonments and disinvestment" ( Boyer, 1983, p.207)

Fairclough (1992; 1995) and Fairclough and Wodak's (1997) critical discourse analysis is derived from Foucault's archaeological and genealogical works as well, exploring the nature of discourse and its relationship with power.In contrast to the Hegelian and Marxist philosophies of history, 'genealogy' is not a holistic project but a perspectival one. Foucauldian genealogy is an history of tracing 'origins' and unearths the force relations operating in particular events and historical developments. Foucault describes his genealogy as an "effective history". ${ }^{10}$ (Focault,1984, cited in Sembou, 2011, p.2)

Flyvbjerg (1998) who studied extensively mega projects, employs the Foucauldian, Nietzschean, and Kantian notions of power in planning discourse and arrives to the conclusion that rationality is often determined by power and not by ideals of reason or democracy. Varied applications of discourse analysis in the urban policy context are demonstrated, Mienhof and Richardson's (1994) collection of essays explores the discourse on poverty in Britain in the 1990s drawn mainly from the mass media.Other approaches for studying discourses include the use of 'rhetoric' (Throgmorton,1993), 'framing' (Rein and Schon, 1993), and storytelling (Forester, 1989; Kaplan, 1986;Mandelbaum, 1990; 1991).

The idea of a 'discourse coalition' is put forward by Hajer (1993), which he presents as a group of actors who share a social construct.

"A discourse coalition is the ensemble of a set of story lines, the actors that utters these story lines, and the practices that conform to these story lines, all organized around a discourse." (Hajer 1993, p. 47).

To dominate a given political realm, a discourse coalition must fulfill two conditions:

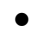

"it dominates the discursive space (discourse structuration) that is, central actors are persuaded by, or forced to accept, the rhetorical power of a new discourse;

$\bullet$

this is reflected in institutional practices (discourse institutionalisation) that is, the actual policy process is conducted according to the ideas of a given discourse." (Hajer 1993, p. 48).

In the Discourse Coalitions and the Institutionalization of Practice: The Case of Acid Rain in Great Britain $^{11}$, Hajer writes about how different were the approaches to the environmental politics discourse in the post-World War II period in the context of Keynesian welfare state and the neoliberalist era under Prime Minister Margaret Thatcher in Britain. It had, of

\footnotetext{
${ }^{10}$ M. Foucault, "Nietzsche, Genealogy, History", in The Foucault Reader, ed. P. Rabinow (Harmondsworth: Penguin, 1984), pp. 87-90.

11 Chapter of the book The Argumentative Turn in Policy Analysis and Planning edited by The Argumentative Turn in Policy Analysis and Planning edited by Frank Fischer and John Forester
} 
course, much more popularity during the first period, considering the values of the state concerned a growth economy based on a social contract between capital and labor in contrast with the Thatcher's aim of reinforcing the industry's competitiveness. (Hajer 1993, p.70)

Linked to these coalitions, Moore Milroy's (1989) deconstructing discourse analysis reveals what was unsaid in planning policy, a certain "tacit" knowledge. Deconstruction is a useful method for studying how planners construct plans that are plausible to the profession and the community and its results can subvert the logic of planning. The strategy of deconstruction is interested in what has been left out, the method uses norms not as guarantors of goodness or plausibility but precisely the opposite, as problematic categories requiring analysis. In Culler's words:

"One frequently finds general agreement, but consensuses adduced to serve as foundations are not given but produced-produced by exclusions of this sort." Milroy 1989, p.316)

In a Habermasian formulation one might ask the question "What are planners recommending here?" in order to see how the proposals are attention-shaping. Specific utterances are interpreted in terms of the model of communicative behavior. In the alternative one instead asks "How is it that these prescriptions are plausible?".

A systematic approach to deconstructing and analyzing arguments in planning has been proposed and refined by various scholars (Dunn, 1993; 1994; Fletcher and Huff, 1990; Gasper and George, 1998). In each of these instances, an argument is deconstructed and mapped by means of some form of diagrammatic representation.

According to Toulmin ${ }^{12}$, arguments are composed of some combination of five components: believe)

$\bullet$ more likely that the audience will believe it)

$\bullet$ warrant)

on, or scope of generalization of the claim, given the grounds, warrants, and backing available)

$\bullet$ claim holds)
Claims (ideas that the arguer would like the audience to Grounds (ideas that lend support to the claim and make it Warrants (logic of the argument)

Backing (reasons why the audience should believe the Qualifiers (modify the claim by indicating a degree of reliance Rebuttals (possible exceptions to the conditions under which a

\footnotetext{
12 Stephen Toulmin in work The Uses of Argument (1922), indicates three major, necessary parts of an argument, along with three additional, optional parts. The three major parts are the claim, the support, and the warrants.
} 
Although there has been much written about the method and its potential value in planning scholarship and practice, there is less evidence that it has actually been used to produce substantive advances. (Kumar and Pallathucheril, 2004). Kumar and Pallathucheril developed a graphical discourse index that is used in this research, with minor modifications according to the specific empirical case study of this thesis, Istanbul Airport. Claims are arranged along the $\mathrm{X}$-axis in chronological order. For the case study, the chronological order represents the planning process and has milestones identified as critical stages or phases in the project. The $\mathrm{Y}$-axis is used to group claims according to which relevant actor to the planning arena made them. The actors are identified during the decision making process of the project. Taking both $\mathrm{X}$-axis and $\mathrm{Y}$-axis into account, the location of an iconic shape on the index represents a type of claim made by a particular participant at a particular time. Finally, iconic shapes are linked together by lines with arrowheads that indicate how and when original claims and sub claims were supported or rebutted during the discourse. In addition to discerning between the main claims and sub claims, the claims are further classified into their types, such as:

- $\quad$ Designative - claim is used to establish the existence (or nonexistence) of an entity, concept, condition, or action

- $\quad$ Definitive- claim used to define the characteristics that a given action, condition, entity, or concept has or does not have

- $\quad$ Evaluative- claim that assigns value (positive or negative) or judges the relative value of a given action, condition, entity, or concept

$\bullet$

Advocative- claim that calls for a course of action (Fletcher and Huff,1990)

Kumar and Pallthucheril (2004) note that the distinction between an argument and a discourse is highly important as one represents a particular idea or intent to a course of action and the latter is a constellation exchange of ideas among the actors involved. Thus, a dimension of the context, the involvement of actors, institutional and organizational structures is introduced. Considering the particular situation of design review, multiple arguments and counterarguments are made in different points in time during the planning process and decision-making process, by elected officials, professionals and the larger public. Therefore, these arguments are all related to each other in a certain percentage and these relations are represented by the arrows in the model suggested by Kumar and Pallthucheril. 
Using this method, the authors have identified many fallacies within the discourse of a particular study case ${ }^{13}$, arguments that are persuasive, yet defective. These fallacies appear when the grounds that support the claims are missing or are false or are based on uncertain beliefs. They can be deliberate or accidental, honest or dishonest, considering the distortion in communication (Forester, 1989) and usually result in an inconsistent decisions-making process and adversity in the planning process (Kumar and Pallthucheril, 2002)

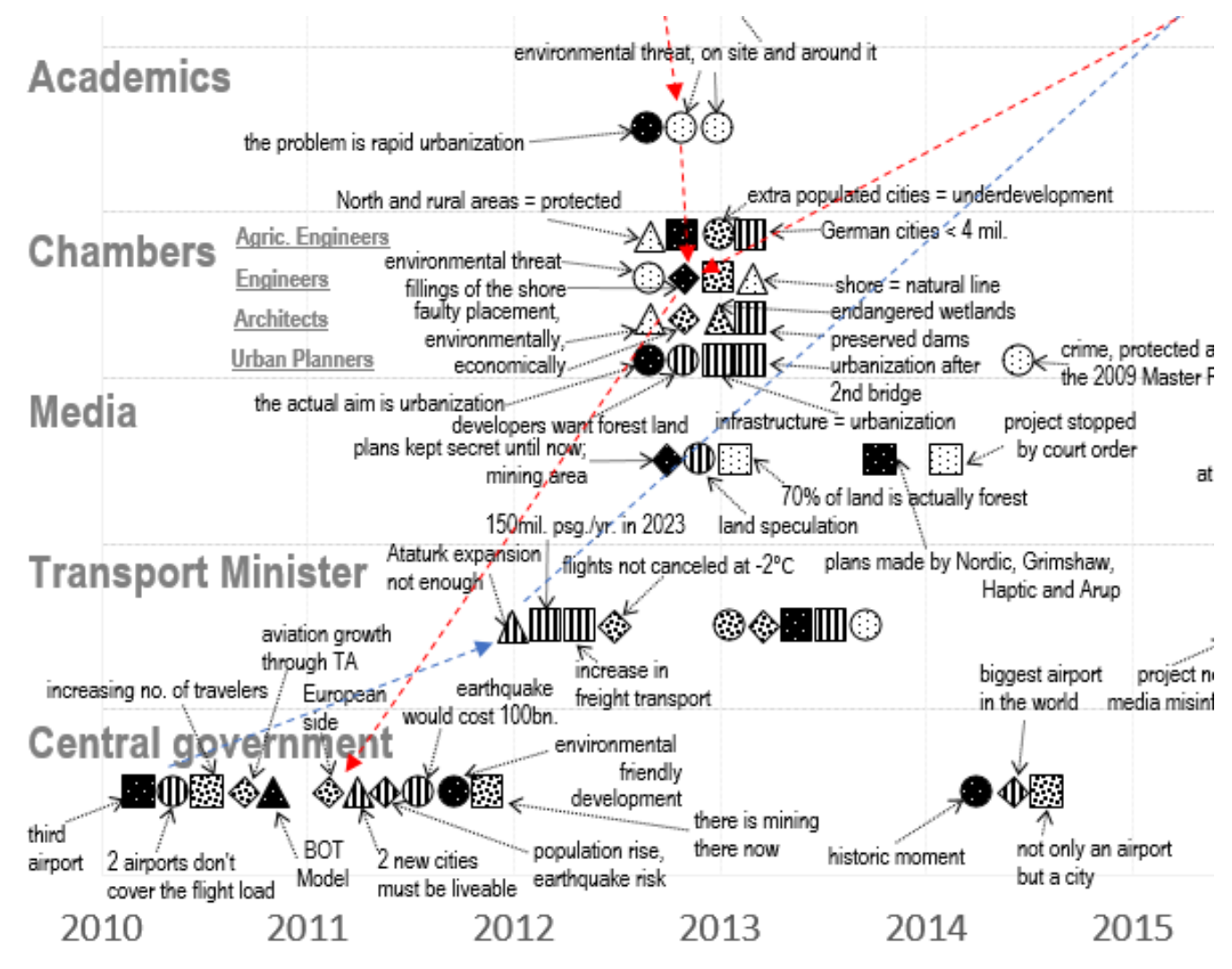

Figure 1 Extract from the discourse index of Istanbul Airport

${ }^{13}$ The design review of Historia ( see Kumar and Pallthucheril- Fallacious argumentation in design review 2002) 


\section{Istanbul, context of planning}

\subsection{New urban policy in Istanbul}

Turkey, as other developing countries has been experiencing a neo-liberal reconfiguration that is now in its final stage. First the liberalization phase in the 1980s, second the implementation of neo-liberal reforms in the post-1990s period and with the year of 2000, a process of configuring a new market-friendly and regulatory role of the state, by abandoning the institutions of the old state, began (Temizel 2007; Dincer 2011a; Enlil 2011; Erbas and Erbil 2012). Since the 1980s, national policy intended to make Istanbul the focal point of a neo-liberal strategy approach to integrate the Turkish economy with global markets. These economic transformations were visible also in the accelerating transformation of urban space, making Istanbul the showcase of the country's new era of internationalism (Enlil 2011; Uzun 2010). In the pace of decentralization as a solution for more effective forms of governance, in 1994, the authority to make and approve plans concerning estates included in the privatization program, was transferred from local authorities to the High Council of Privatization (OIB). This not only provided exceptional development rights to the owners of these valuable properties located in city centers, but also marginalized the authority of the traditional planning and administration institutions, creating major social, economic and cultural impacts (Dincer 2011a; Erbas and Erbil 2012). By 2000, other leading structural changes as integration of urban fringe to the core, de-industrialization, urban sprawl, renewal of historical areas and re-development of brown field areas have been introduced through a complex agenda of urban regeneration policies into the urban planning practices. The central government created additional laws to enable urban renewal as an exclusive planning tool and therefore making it a debated planning issue in the last decade. (Temizel 2007; Dincer 2011a) Engagement of institutions of central government in decision-making over planning at local scale, transforms the clash of interests in many projects from being the small scale impacts of social, economic or environmental concerns regarding planning to actual questioning of the whole planning system in Istanbul, Turkey. (Dincer 2011 a, 2011b; Enlil 2011; Ergun 2004)

While the purpose of the many projects initiated by the government seems to be in the name of upgrading the built environment and improving the living conditions of the poor or creating new infrastructure for the city, they are made within a top-down approach to planning, reducing to just a transformation of physical space and neglecting the social, economic and environmental dimensions. These aspects along with the unwillingness of government to allow any participation of civil society become the focus of discontent and protest of many engaged in resistance. (Erbas and Erbil 2012; Temizel 2007). Strong opposing governance forms come together: non-governmental organizations, neighborhood associations, Chamber of Architects and Urban Planners and urban social movements are formed with the aim of more justice and inclusionary process in planning. This situation culminated with the events of 28 may 2013 when thousands of people fought against the 
"neo-liberal urban development agenda of the government" (Taksim Dayanismasi 2013) ${ }^{14}$.

\subsection{Vision}

In 2011, Turkish president Tayyip Recep Erdogan officially announced the Justice and Development Party's (AKP's) "2023 Vision", aiming to make it one of the world's 10 largest economies by its centenary in 2023.

However, the vision was a much older idea, but on local scale, just for the city of Istnabul. Three months after the 1999 earthquake, without even approving the Earthquake masterplan, "2023 vision" for Istanbul appeared on the agenda. It was actually a strategy called "mega transformation" ("Mega dönüşüm") that was presented before and now with a change of name puts forward "mega transformation projects", "neighborhood transformation projects related to earthquake disaster" and these were pointed to be the main way development path. (Yapici, 2017) It is already in those times that was decided that Istanbul becomes a "corridor city", a goal declared by Topbas, mayor of Istanbul Metropolitan Municipality (Istanbul Büyükşehir Belediyesi-IBB). Mucella Yapici, secretary of Chamber of Architects Istanbul relates that moment with all the transport projects Istanbul did and has in plan to do: $3^{\text {rd }}$ bridge, Marmaray, $3^{\text {rd }}$ airport, Istanbul Canal Project, etc.

The AKP introduced the 2023 Vision in 2011 during the general elections that resulted in Erdogan's third term as prime minister. Critics says that the ambitious goals, which include a $10 \%$ yearly average growth rate to reach $\$ 2.6$ trillion in GDP, are idealistic promises made by a leader seeking electoral success, Jean-Pierre Lehmann, professor of international political economy at Oxford University's Centre for Economics and Foreign Policy Studies says ( Kayagil- G20, 2015)

Lehmann also points out that the obsession with growth targets, at the possible expense of society, could prove dangerous and harmful. The AKP's path to growth and social development has been inconsistent, with policymakers looking at these economic targets as an end rather than as a response to the more important question of what type of society the country wants. This is clearly apparent in the already stagnating economy, the high political instability and the tensions caused by unclear and ill-defined strategies in combatting citizen dissatisfaction.

\subsection{Istanbul Airport mega project overview}

Strongly linked to the 2023 Vision of Turkey, the $3^{\text {rd }}$ airport, now with its name Istanbul Airport is one of the mega projects that will bring Turkey among top 10 economically powerful countries. Istanbul Airport opened its first stage on $29^{\text {th }}$ October 2018, which took place on the 95th anniversary of Turkey's establishment as a republic. For the first time in the history the celebration of the Republic is held in Istanbul rather than Ankara.

${ }^{14}$ Online Source: http://taksimdayanisma.org/?lang=en 
When fully completed, Istanbul Airport will be the world's major hub of transport and aviation, as well as having the globes biggest duty-free area. Replacing the Istanbul Ataturk airport, ultramodern architecture and technology have been used with the aim of getting passengers quickly and smoothly to their chosen destination.

The airport is under construction on an area of 76.5 million square meters to the north of Istanbul, $35 \mathrm{~km}$ away from the city center and promises to be the world biggest airport biggest airport and largest "Build-Operate-Transfer" project in the history of the Republic of Turkey. (CAPA, 2016; IGA website).With an annual passenger capacity of 200 million (DHMI, 2013), it will respond to the growing needs of the city, which can no longer be fulfilled by the two existing airports - Ataturk, with 37 million annual passengers, and Sabiha Gökçen, with 13 million (Turkish Forum Archive, 2010). Furthermore, this project is planned to be extended by an airport city (CSB, 2014) with a central innovation district, hotels, retail and commercial office space, logistic centers, an expo and convention center, public space, and metro and high-speed rail connections to Istanbul and beyond (CAPA, 2016). On its journey to become "the hub for global aviation", Istanbul Airport will emerge as a strong player in cargo transportation as the trade axis shifts to the Asia-Pacific region. Istanbul Airport will render Turkey an attraction center not only in passenger transport, but also in trade.

Istanbul Airport will distinguish itself from a myriad of other build-operate-transfer projects thanks to the added value it will offer for the Turkish economy. Following the completion of all phases in 2025, the total direct and indirect employment will go as high as 225,000 employees and the household income will rise up to 4.4 billion dollars.

The project in numbers looks like this:

- total investment- $€ 10.2$ billion

- $\quad 3500$ ha (1100 ha services, 165 pedestrian bridges, 8 control towers, parking for 70000 cars, 1 mall, 1 aviation medical center

- 200 million passengers- 90 million phase one (that is finished)

- 300 different destinations

- 12 awards (design architecture, economic and environmental and social sector)

- $\quad 3,109$ suppliers

- $\quad$ revenue flow into the Treasury in 25 years- $€ 22.2$ billion + VAT

- $\quad 21,500 *$ - total employment (as of 31 dec 2016)-225,000 employees in total; indirect Employment- 1.5 million; direct Employment- 100,000

- $\quad$ household income will rise up to 4.4 billion dollars

\subsection{Institutional and legal framework- IGA (Istanbul Grand Airport)}


IGA was founded on October 7, 2013 to construct and operate Istanbul Airport for 25 years. The IGA journey started on May 3, 2013 when DHMI (General Directorate of State Airports Authority of Turkey) awarded the contract for construction and operation of Istanbul Airport to the Cengiz-MAPA-Limak-Kolin-Kalyon Consortium. Having won the bid for the project, the consortium founded a new company under the name "iGA". Each of the investors has an equal share of $20 \%$ in IGA. Cengiz-MAPA-Limak-Kolin-Kalyon Joint Venture operates in different industries nationwide and around the world including construction, energy, tourism, mining, port and airport management. The consortium has undertaken eight airport construction projects so far.

"Already awarded for its design and value-added projects before its opening, the name of Istanbul Airport will be written in golden letters in the history of aviation as "the world's largest airport built from scratch." -message from the Board of Directors of IGA. But beyond this message, it is not surprising to see how the new airport development is presented and marketed as a victory for the whole country, the political sublime together with the technological sublime are known features of megaprojects.

"Bugün aslında biz sadece bir havalimanı değil, bir zafer anıtı inşa ediyoruz." Recep Tayyip Erdoğan (2018) - "Today we are not building just an airport, but rather we won a victory"- a fragment from the speech of Recep Tayyip Erdogan at the opening ceremony of Istanbul Airport. "Yeni Türkiye'yi Inşa Ediyoruz"- The statement "We are building the new Turkey"- is also the message present on all billboards and commercials regarding the new airport.

Nordic and partners, architecture office, developed the concept design of the airport and describe the Istanbul New Airport as celebrating the city's long history as the gateway between two worlds. However, they do not accept the affiliation with the decision over the area chosen for the project, the north forest area of the city, also protected area in the 2009 Masterplan or the non-transparent planning process and deaths on the constructions site due to neglect.

\subsection{Impact of the Istanbul Airport mega project}

Environmental and social impact assessment are two of the key issues in megaproject development. For environmental and social effects of projects, one similarly finds that such effects often have not been taken into account during project development, or they have been severely miscalculated, such problems often destabilize habitats, communities and megaprojects themselves, if not dealt with carefully. (Westport, CT: Praeger Publishers, 1998; Paris: OECD, 1993; Roger W. Vickerman, 1994) Serious issues are identified in the project for the Istanbul Airport. The first EIA report was prepared in 2013, by AK-TEL Engineering Co., on behalf of the Ministry of Transport, Maritime and Communications (MTMC). Although it received a positive decision from the Ministry of Environment and Urbanism (ENVIRON, 2015), the construction was halted by Istanbul's Fourth Administrative Court, due to claims on the project's negative environmental impact. A new EIA report was put into effect in 2014, emphasizing the necessity for a new airport (CSB, 2014). 
Deforestation is a serious concern when the scale of the projects is taken into consideration. $80 \%$ of the total project area of the third airport consists of forested land (Gürtler, 2016). There are also problems connected to ecosystems. UCTEA warns that Istanbul will be deprived of water as the construction site of the third airport threatens ecologically protected and sensitive areas including water basins (CAPA, 2016). Additionally, the third airport is planned on the migration routes of birds, which is hazardous for the ecosystem. This not only violates the Bern Convention (1979), but also causes possible airplane crashes (Arslangündoğdu, 2014).

Consequently, ENVIRON was commissioned by IGA (Istanbul Grand Airport) for the preparation of the Environmental and Social Impact Assessment (ESIA) in order to support funding applications to international financial institutions. With this report, the present (before project) state of the Project Site has been determined, the significance of the potential environmental and social impacts has been evaluated, and the mitigation measures likely to be taken in order to minimize the defined impacts of the project have been introduced. In line with the Environmental Management and Monitoring Program specified in the Environmental and Social Impact Assessment (ESIA) Report prepared by Ramboll Environ (UK) and the Environmental and Social Action Plan (ESAP) prepared by the Lenders' Technical Advisor (LTA), the Environmental Management Department continues to carry out inspection and audit works with respect to checking of the site compliance with Turkish Environmental Legislation, IFC (International Finance Corporation) Standards, the Equator Principles, and TS EN ISO 14001:2015 EMS requirements, and planning and site application of the necessary actions.

IGA put together the 2016 Sustainability Report in light of the principles of GRI G4 Core. Corporate governance, environmental sustainability, business and social management practices at international standards are collated in a report, with a view to offer a powerful contribution to the development of the sustainability culture in Turkey as well as the sustainable development of the country. As part of the Stakeholder Engagement Plan, more than 100 Meetings Involving 46 Stakeholders were made.

Unfortunately, the number is extremely low for the size of the development and looking closely at the stakeholder list and considering that the Sustainability Committee, established by Sustainability Organization IGA, is chaired by the Company's CEO Yusuf Akçayoğlu, we can easily deduct that it is not a participative and an equitable process. IGA Sustainability Committee is the decision maker in the process of identifying the corporate sustainability priorities for the 2016 Sustainability Reporting process.

Since neoliberal urban policies prioritize urban growth and investments in order to comply with global flows, public interests are frequently overlooked (Baysal, n.d.). In the case of these mega-projects it is possible to identify two types of constraints - (1) the destroying forestlands or farmlands belonging to the state treasury for the same purpose, mentioned before and (2) the urgent expropriation to empty lands for construction. A problem affecting the community is related to property rights.

Consequently, Northern Forests Defense (2015) underlines that megaprojects violate property rights through urgent expropriation. Centralized government and top-down 
mechanisms facilitate this process, whilst legal frameworks remain insufficient to secure the rights of citizens.

Therefore, in addition to documentation and the education of the public, the Istanbul Chamber of Architects and environmental NGOs applied to the court for a stay of execution for the mega-projects. Marschall and Aydogan (2015) mention that 75 lawsuits were filed against the various mega projects (including the Northern Marmara Motorway, the Third Bridge and the Third Airport) by the Chamber of Architects from 2007 to 2012. Nevertheless, the construction work was not halted despite the decision of the court in favor of cancellation. Moreover, in some cases the decisions for cancellation by local administrative courts were annulled by higher courts.

\subsection{Istanbul Airport mega project discourse index}

The discourse index was created by reviewing 300 news related to the development of the Istanbul Airport project, from different sources: iga website, Sabah daily (as being the most widespread newspaper, also available in English), but also opposition newspapers like Radikal or Diken. Moreover, 20 interviews were made with actors involved and against the planning process: urban planners, engineers, economists, lawyers, architects, academics, ngo representatives, chambers representatives, etc. Their expertise was also carefully chosen as strongly related with the subject: urban planning, environmental aspects, political science, sociology, economy, judiciary, etc.

By looking at the graphic, still a work in progress, one can identify easily the fallacies made throughout the discourse, how some arguments have rather a political motivation to it than a technical one. Moreover, one can identify how arguments support themselves, but also how some actors can contradict themselves throughout the discourse. For example, the Ministry of Transport has a good line of presenting the projects as environmental- friendly, but it also presents the EIA (environmental impact assessment plan) as a waste of time. Fallacies in the discourse mean fallacies in decision making. 


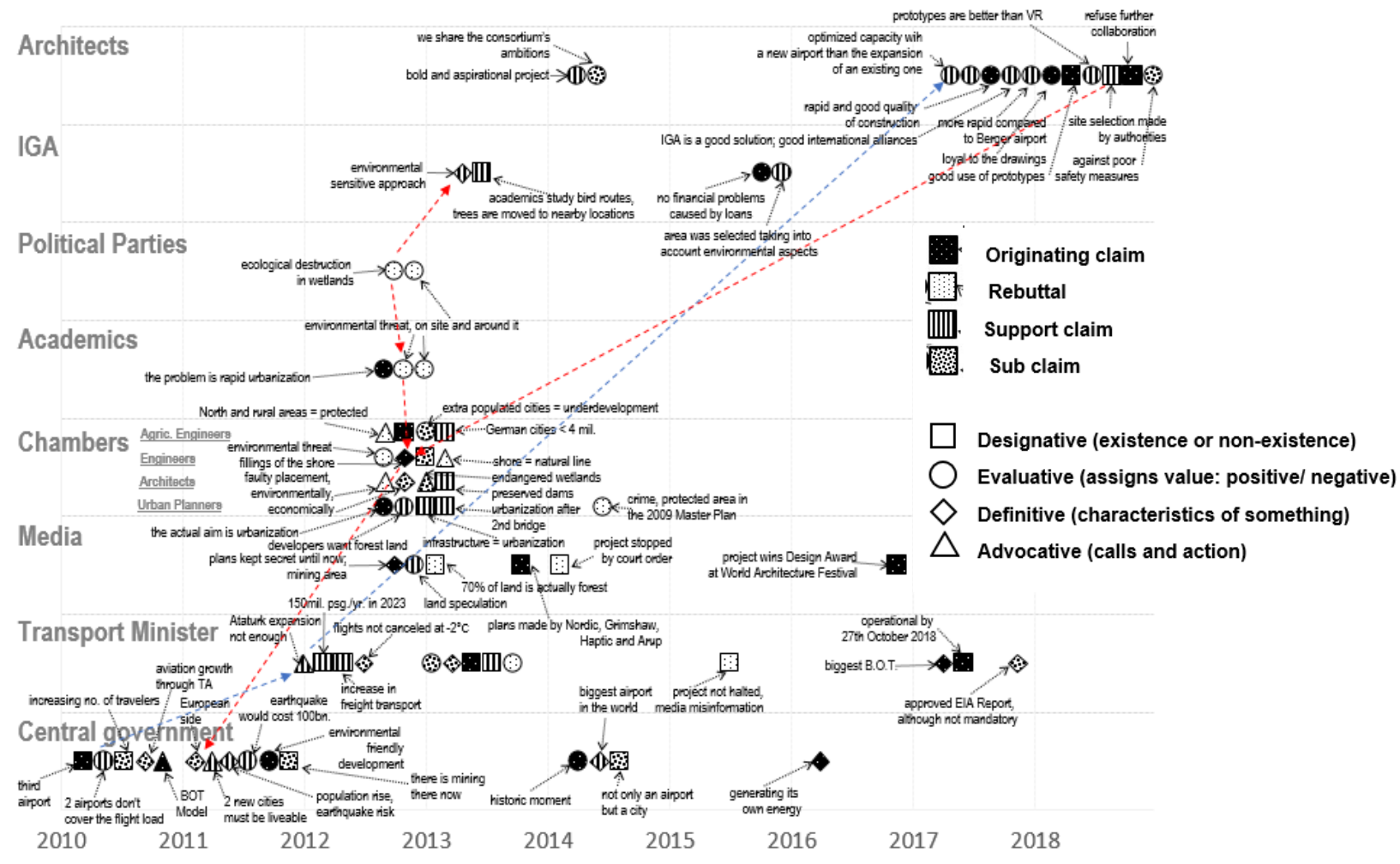

Figure 2 Discourse index of Istanbul Airport 


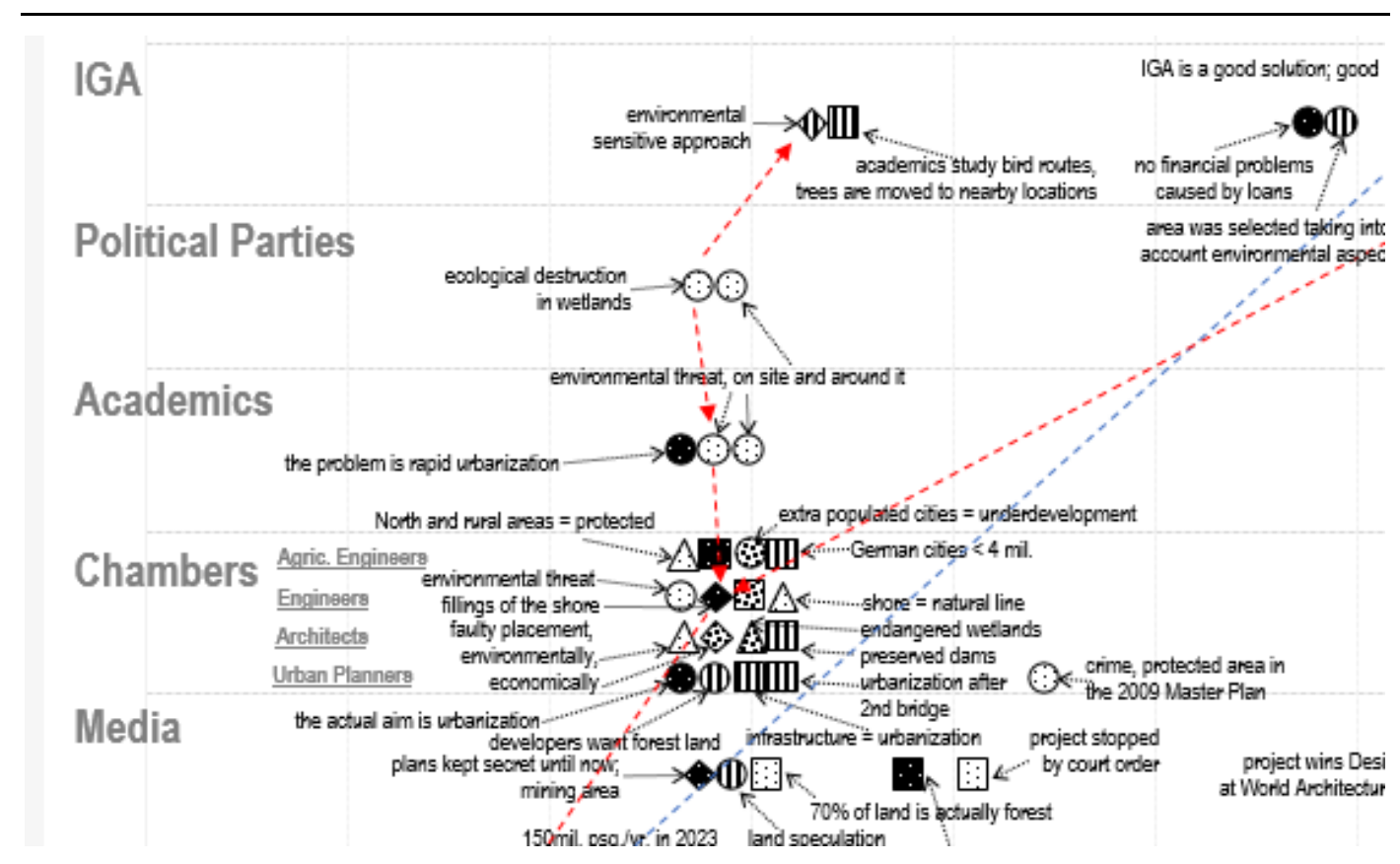

Figure 3 Extract from the discourse index of Istanbul Airport

\section{References}

Altshuler, A. and D. Luberoff (2003) Mega-projects. Brookings Institution,Washington, DC. Bachrach, P. and Baratz, M. S. (1962).'Faces of Power'. The American Political Science Review. 56(4).947-952.

Brenner, N. and N. Theodore (eds.) (2004)Spaces of neoliberalism. Urban restructuring in North America and Western Europe. Blackwell, Oxford.

Butler, T. (2007). 'Re-urbanizing London Docklands: Gentrification, Suburbanization or New Urbanism?'. International Journal of Urban and Regional Research. 31(4), 759- 779

Brenner, N. (2000).'The Urban Question as a Scale Question: Reflections on Henri Lefebre, Urban Theory and the Politics of Scale'. International Journal of Urban and Regional Research. 24(2). 362-378

Brownill, S. (1990) Developing London's Docklands: another great planning disaster?. Urban and Regional Development Series. Sage Publications. 104-105

Bruns, J. (2012). Hafencity Hamburg: Making a New Downtown. Online source: http://learningcitiesplatform.files.wordpress.com/2012/07/lcp-hafencity-hamburg-june2012s.pdf; Last date of access: 11.10 .2013

Butler, T. (2007). 'Re-urbanizing London Docklands: Gentrification, Suburbanization or New Urbanism?'. International Journal of Urban and Regional Research. 31(4), 759- 779 Butuner, B.(2006). 'Waterfront Revitalization as a Challenging Urban Issue.'42nd. ISoCaRP Congress.1-11.

Castells, M. (1978) City, class and power.Macmillan, London.

Crilley, D. (1993) Mega structures and Urban Change: Aesthetics, ideology and design' . The Restless Urban Landscape . 1(1).127-164. 
Davis, M. (1990) City of Quartz

Fainstein, S. (2000). 'New Directions in Planning Theory'. Urban Affairs Review. 35(4).451478.

Fainstein, S. (2001).'The City Builders: Property Development in New York and London, 1980-2000. 2nd ed. Lawrence: University Press of Kansas. 160-185

Fainstein, S. (2009). Mega-projects in New York, London and Amsterdam'. International Journal of Urban and Regional Research

Feldman, M. (1999).'Urban Waterfront Regeneration in the Baltic States: The Case of Tallinn', in Hedegaard, L. , Lindstrom, B. , eds. The NEBI Yearbook 1999 North European and Baltic Sea Integration. Berlin: Springer. Ch. 2. 121-135

Flyvbjerg, B. (2004). 'Five Misunderstandings about Case-Study Research', in C. Seale, G. Gobo, J. F. Gubrium and D. Silverman, eds. Qualitative Research Practice. Sage. Thousand Oaks. 420-34.

Forester, J. (1999).Planning in the face of power. Berkley: University of California Press.

Gans, H.J. (1991) People, plans, and policies. Russell Sage, New York.

Goodwin, R.(1999). 'Redeveloping Deteriorated Urban Waterfronts: The Effectiveness of U.S. Coastal Management Programs', Coastal Management,27(1999), 239-269

Gordon, D. L. A. (1997b). Battery Park City: politics and planning on the New York waterfront. Amsterdam, Gordon and Breach.

Gordon, D.L. A. (1997a).'Managing the Changing Political Environment in Urban Waterfront Redevelopment'. Urban Studies.34(1), 61-83

Granath, K. (2005). Beggar or Chooser?42 years of waterfront development in Baltimore Inner Harbor. What did Baltimore learn?. Ph.D. Baltimore: Institute for Policy Studies, Johns Hopkins University, Baltimore.

Hall, P.G. (2002) Cities of tomorrow. Third edition, Blackwell, Oxford.

Harms, H. (2009). 'Changes on the Waterfront - Transforming Harbor Areas'. The Future of Shrinking Cities - Problems, Patterns and Strategies of Urban Transformation in a Global Context. 1 (1), 37-49. Online source: http://www.rop.tuortmund.de/cms/Medienpool/Downloads/The_Future_of_Shrinking_MG-2009-01.pdf ; Last date of access: 10.11.2013

Harvey, D. (1973).Social Justice and The City. Oxford: Blackwell Publishers. Online Source:http://oneboxofturkishdelights. files.wordpress.com/2013/07/david-harvey-socialjustice-and-the-city.pdf

Harvey, D. (1989).' From managerialism to entrepreneurialism: The transformation in urban governance in late capitalism'. Geografiska Annaler. 71 B (1), 3-17

Harvey, D. (1992)The Condition of Postmodernity- An Enquiry into the Origins of Cultural Change. 2nd ed. Oxford: Blackwell Publishers.

Harvey, D.(1991) 'A view from Federal Hill'. The Baltimore Book: New Views of Local History. Philadelphis: Temple University Press, 226-249.

Harvey, D.(2008).' The Political Economy Of Public Space', in A. Zieleniec, eds. Space and Social Theory.London: Sage. Ch.4.

Healey, P. (1997).'Collaborative planning- Shaping Places in Fragmented Societies'. 1st. New York: Palgrave Macmillan.

Healey, P. (2003).' Collaborative planning in Perspective'. Sage. 2(2), 101-123 
Healey, P. (2006).'Collaborative planning- Shaping Places in Fragmented Societies'. 2nd ed. New York: Palgrave Macmillan.

Hinsley, H. and Malone, P. (1996).'London Planning and Design in Docklands', in P. Malone, eds. City Capital and Water. London: Routledge. Ch.3.

Holland, J.H. (1995)Hidden Order: How Adaptation Builds Complexity, New York: Basic Books.

Hoyle, B. (2000). 'Global and Local Change on the Prot-City Waterfront'. American Geographical Society. 90 (3), 395-417.

Jacobs, J. (1961) Death and life of great American cities. Vintage, New York.

Lefebre, H. (1968) Le Detroit a le ville.

Levine, M.V. (1987a). 'Response to Berkowitz: Economic Development in Baltimore: Some Additional Perspectives', Journal of Urban Affairs, 9 (2), 133-138.

Levine, M.V. (1987b) Downtown Redevelopment as an urban growth strategy: A Critical Appraisal of the Baltimore Renaissance, Journal of Urban Affairs, 9(2).103-123.

Loftman, P. and Nevin, B. (1995) 'Prestige Projects and Urban Regeneration in the 1980s and 1990s: a review of benefits and limitations', Planning Practice \& Research, 10(3-4). 299-316.

Logan, J. and H. Molotch (2007). Urban Fortunes, 20th anniversary edition. University of California Press, Berkeley.

Malone, P. (1996). City Capital and Water. 1st ed. London: Routledge.

Marshall, R. (2001). 'Comlexity on the Urban Waterfront', in R. Marshall,eds. Waterfronts in Post-industrial Cities.London: Spon Press.

Massey, D. (1994). A global sense of place: From Space, Place and Gender. Minneapolis University of Minnesota Press

Meyer,H.(2004).' City and Port: Urban Planning as a Cultural Venture in London, Barcelona, New York, and Rotterdam. Changing Relations between Public Urban Space and Large Scale Infrastructure'. International Journal of Urban and Regional Research. 28(1).229-233

Millspaugh, M. L. ( 2003). 'The Inner Harbor Story'. Issue of Urban Land. 1 (1), 36-41.

Molotoch, H.L. (1987).'The city as a growth machine: Toward a political economy of place'. Journal of Sociology. 82(2).309-32.

Mumford, L (1938) Technics and Civilisation

Mumford, L. (1967) My myth of The Machine.

Mumford, L. (1937) "What is a City?", in LeGates, R.T. and Stout, F., eds., (1996) The City Reader, London: Routledge.

Sassen, S. (2001).'Global Cities and Developmentalist Sates: How to Derai What Could Be an Interesting Debate: A Response to Hill and Kim'. Urban Studies. 38(1).2537-2540.

Swyngedouw, E., F. Moulaert and A. Rodríguez (2004) Neoliberal urbanization in Europe: large scale urban development projects and the new urban policy. In N. Brenner and N. Theodore (eds.), Spaces of neoliberalism. Urban restructuring in North America and Western Europe, Blackwell, Oxford.

Swyngedouw, E. (2005). 'Governance Innovation and the Citizen: The Janus Face of Governance-beyond-the-State'. Urban Studies 42(11), 1991-2006 
Swyngedouw, E., Moulaert, F. and Rodriguez, A. (2002) Neo-liberal urbanization in Europe: large-scale urban development projects and the new urban policy, Antipode, 34 (3), pp 542-577.

Orueta, F.D. and Fainstein, S. S.(2009). 'The New Mega-Projects:Genesis and Impacts.International'. Journal of Urban and Regional Research. 1(1). 760-766

Parker, S. (2003). Urban Theory and the Urban Experience: Encountering the City. 1st Ed. New York: Routledge. Ch.7. 120-140.

Virilio, P. (1977) Speed and Politics: An Essay of Dromology.

Yin, R. K. (1994).' Case Study Research. Design and Methods'. 2nd ed. Thousand Oaks: Sage. 